\title{
Pas de deux: Active ulcerative colitis in an HIV-positive patient
}

\author{
DAVID C PEARSON MD, LLOYD R SUTHERLAND MD, STEPHAN URBANSKI MD
}

DC Pearson, LR Sutherland, S URbanski. Pas de deux: Active ulcerative colitis in an HIV-positive patient. Can J Gastroenterol 1996;10(5):307-309. A 40-year-old male who was found to be human immunodeficiency virus-positive when he presented with bloody diarrhea in 1986 is described. Clinical, laboratory, endoscopic and histological findings were all compatible with ulcerative colitis, and stool cultures were repeatedly negative for pathogens. Colitis was initially mild and controlled with intermittent oral aminosalicylic acid products. Since 1993 he has had more significant symptoms requiring prednisone up to $40 \mathrm{mg} /$ day. Repeat colonoscopy disclosed pancolitis and biopsies did not show evidence of cytomegalovirus infection. He has not had an acquired immune deficiency syndrome-defining illness. CD4 cells fell below normal as his colitis worsened. This case raises questions about immune regulation in ulcerative colitis because the patient has active disease in addition to a reduced number of $\mathrm{T}$ helper cells. It also presents a difficult management problem because the patient has a limited life expectancy and is reluctant to accept colectomy, and further immunosuppressive therapy may be dangerous.

Key Words: Human immunodeficiency virus, Therapy, Ulcerative colitis

\section{Pas de deux : colite ulcéreuse évolutive chez un patient VIH positif}

RÉSUMÉ: On décrit ici le cas d'un homme de 40 ans chez qui on a découvert une séropositivité à l'égard du virus de l'immunodéficience humaine lorsqu'il s'est présenté pour diarrhée sanguinolente. Les analyses cliniques, les analyses de laboratoire, l'endoscopie et les tests histologiques étaient tous compatibles avec une colite ulcéreuse et les cultures de selles se sont toujours révélées négatives à l'égard d'organismes pathogènes. Au début, la colite était légère, contrôlée par l'administration intermittente par voie orale de produits dérivés de l'acide aminosalicylique. Depuis 1993, les symptômes se sont aggravés, nécessitant jusqu'à 40 mg par jour de prednisone. Une nouvelle coloscopie a révélé la présence d'une pancolite et les biopsies n'ont montré aucun signe d'infection au cytomégalovirus. Le patient n'a pas présenté de maladie reliée au diagnostic du syndrome de l'immunodéficience acquise, ses CD4 ont chuté sous la normale et sa colite s'est aggravée. Ce cas soulève des questions au sujet de l'immunorégulation dans la colite ulcéreuse, parce que le patient souffre d'une maladie évolutive en plus d'avoir un nombre réduit de lymphocytes T auxiliaires. Ce cas représente également une difficulté sur le plan thérapeutique parce que le patient a une espérance de vie limitée. Il est réticent à subir une colectomie et la poursuite du traitement immunosuppressif pourrait être dangereuse.
$\mathrm{I}$ nflammatory bowel disease (IBD) is thought to result from inappropriate activation of the body's immune system, and current medical therapy is aimed at modulating this immune response. Human immunodeficiency virus (HIV) infection slowly destroys the patient's T helper cells and leads to immunosuppression, infection with opportunistic pathogens and eventually death. One may therefore expect IBD to improve in the presence of HIV infection. This may be the case with Crohn's disease (CD) $(1,2)$, but there are reports of active ulcerative colitis (UC) in the face of HIV infection with undetermined $(3)$, normal $(4,5)$ and diminished CD4 cell counts $(6,7)$. We report a case of chronically active UC in an HIV-infected patient with a reduced CD4 lymphocyte count.

Departments of Medicine and Pathology, University of Calgary, Calgary, Alberta

Correspondence: Dr David Pearson, 320-1175 Cook Street, Victoria, British Columbia V8V 4A1. Telephone 604-383-3365, fax 604-383-9405, e-mail dcpearson@gvhs.gov.bc.ca

Received for publication April 18, 1995. Accepted April 22, 1996 


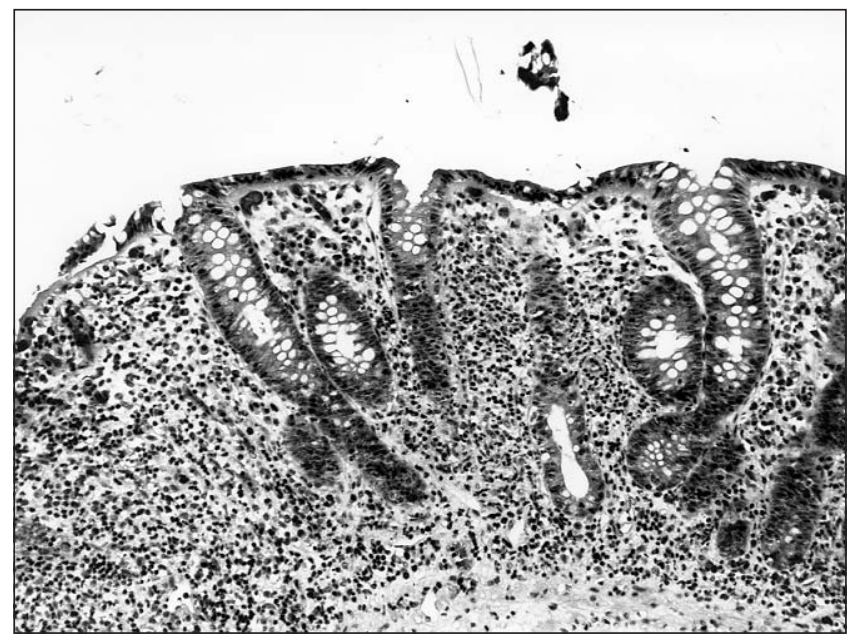

Figure 1) Representative section of a colonoscopic biopsy obtained in March 1994. There is a moderate increase in the mixed cell population of the lamina propria with shortening, fission and drop-out of colonic crypts as well as migration of polymorphonuclear cells through the crypt epithelium. The features are those of chronic active ulcerative colitis of mild intensity. There is no evidence of viral inclusions or malignancy (hematoxylin and eosin $x 46$ )

\section{CASE PRESENTATION}

A 40-year-old man was simultaneously diagnosed with HIV infection and UC in March 1986. UC diagnosis was based on a history of frequent bloody bowel motions and abdominal cramps with negative stool cultures and confluent proctosigmoiditis on sigmoidoscopic examination. Colon biopsies showed acute inflammation with cryptitis, crypt abscesses and goblet cell depletion, but no viral inclusions (Figure 1). He had a negative family history for IBD but had recently quit a 15-pack/year smoking habit. His only risk for HIV exposure was homosexuality. He received zidovudine from December 1989 to January 1993, switching to dideoxyinosine until March 1994. He has not had an acquired immune deficiency syndrome-defining illness and his most recent CD4 cell count was 300 cells/mL (normal range 353 to 1316$)$.

The patient's UC was mild and controlled with intermittent oral sulphasalazine until December 1989 when he began having more frequent episodes of bloody stools and intestinal cramps, which responded to 2 to $3 \mathrm{~g} /$ day oral sulphasalazine. In April 1993 he presented with a four-month exacerbation of his symptoms which had not adequately responded to sulphasalazine. He initially responded to the addition of a tapering course of prednisone $25 \mathrm{mg} /$ day, but over the ensuing months he required larger doses to control the symptoms. Attempts to reduce the prednisone dose to less than $20 \mathrm{mg} /$ day resulted in increased cramps and bloody diarrhea. He did not respond to the addition of cortifoam enemas on retiring or the temporary discontinuation of sulphasalazine.

Because dideoxyinosine has been associated with diarrhea (2), it was stopped in March 1994 without effect. A

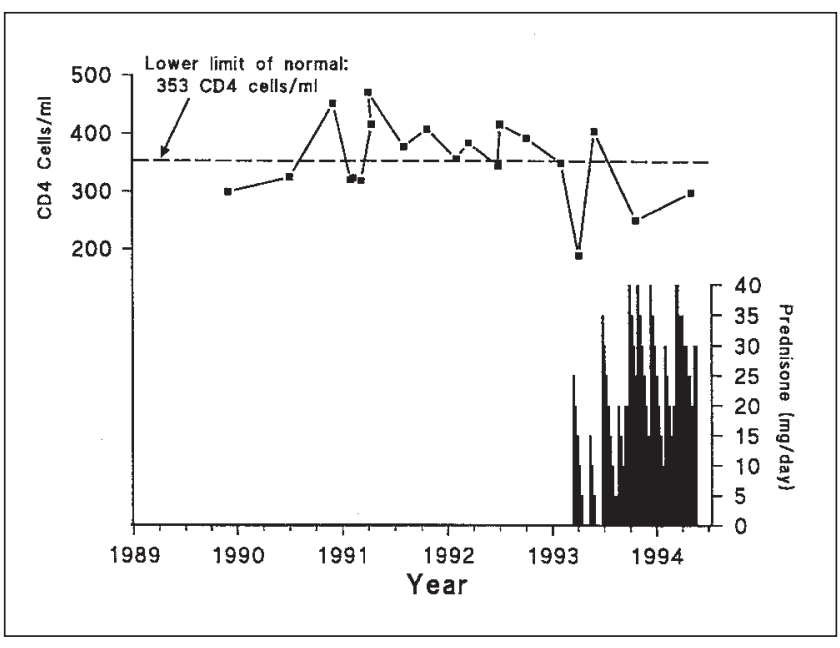

Figure 2) Schematic representation of CD4 cell count and prednisone use, January 1989 to June 1994

colonoscopy performed in April 1994 revealed contiguously inflamed mucosa to $55 \mathrm{~cm}$ without evidence of Kaposi's sarcoma. Repeated colonic biopsies over several years have all shown a mixed inflammatory infiltrate of the lamina propria with polymorphonuclear cell infiltration and focal destruction of the epithelium, as well as crypt shortening, fission and drop-out, features of chronic active idiopathic UC (Figure 1).

The patient has anti-cytomegalovirus (anti-CMV) immunoglobulin $G$, but viral culture and electron microscopic examination of the biopsies for CMV have been negative, and viral inclusions have not been identified histologically. Repeated stool cultures for bacterial pathogens were negative, while microscopic examination showed Endolimax nana and Entamoeba coli on one occasion each. His course to June 1994 is summarized in Figure 2. He has not had fevers, chills, significant weight loss or extra-intestinal manifestations of UC. Colectomy has been discussed, but he prefers to continue medical therapy.

\section{DISCUSSION}

Making the diagnosis of IBD in the face of HIV infection may be difficult because diarrhea is a common complaint among HIV-infected patients (8). Symptoms mimicking IBD may be caused by a variety of intestinal infections, and in HIV-infected patients such symptoms have been reported due to CMV $(9,10)$ and Kaposi's sarcoma $(3,4)$. The pathogenic role of Kaposi's sarcoma in the latter cases $(3,4)$ is unclear because both presented with a severe UC-like illness and were subsequently found to have extensive colonic Kaposi's sarcoma. The lack of evidence of any alternative diagnoses in our patient, the chronic nature and relapsing course of his disease, its typical colonoscopic and histological appearance, and its response to sulphasalazine and prednisone all support the diagnosis of idiopathic UC.

The combination of IBD and HIV is rare. There are three other well-documented cases in the literature of active UC in HIV infection (5-7). In these reports the disease was ac- 
tive, with CD4 counts of 260 to 520 cells $/ \mathrm{mL}, 500$ cells $/ \mathrm{mL}$ and 170 to 220 cells/mL. Our patient's CD4 cell count was as low as 252 cells/mL over the past several months and he still required significant doses of prednisone for symptom control. In contrast, CD appears to remit with HIV infection, even when the CD4 cell count is within normal limits $(1,2)$, although recently a case of active CD was reported in an HIV-infected individual with a CD4 count of 480 cells $/ \mathrm{mL}$ (11). An intact $T$ helper cell population may be required for CD, while UC may be related to an imbalance in lymphocyte populations rather than to the number of T helper cells. Alternatively, UC may be due to an abnormal reaction to an exogenous immune stimulus, perhaps even the HIV, a situation that may be potentiated in an immune-compromised individual.

This case also presents a difficult management problem because conventional medical therapy implies further immunosuppression of an HIV-infected individual. Continued corticosteroid therapy carries the risk of steroid side effects and an increased risk of precipitating symptomatic CMV ACKNOWLEDGEMENTS: This paper was a winning entry in the Inflammatory Bowel Disease Resident Case Study Competition, supported by an educational grant from Astra Pharma Inc.

\section{REFERENCES}

1. James SP. Remission of Crohn's disease after human immunodeficiency virus infection. Gastroenterology 1988;95:1667-9.

2. Pospai D, René E, Beaugery L, et al. Crohn's disease stable remission after human immunodeficiency virus (HIV) infection. Gastroenterology 1994;106:A2878. (Abst)

3. Biggs BA, Crowe SM, Lucas CR, Ralston M, Thompson IL, Hardy KJ. AIDS related Kaposi's sarcoma presenting as ulcerative colitis and complicated by toxic megacolon. Gut 1987;28:1302-6.

4. Weber JN, Carmichael DJ, Boylston A, Munro A, Whitear WP, Pinching AJ. Kaposi's sarcoma of the bowel presenting as apparent ulcerative colitis. Gut 1985;26:295-300.

5. Franke M, Kruis W, Heitz W. First manifestation of ulcerative colitis in a patient with HIV infection. Gastroenterology 1990;98:544-5. (Lett)

6. Bernstein CN, Snape WJ Jr. Active idiopathic ulcerative colitis in a patient with ongoing HIV-related immunodepression. Am J Gastroenterol 1991;86:907-9.

7. Sturgess I, Greenfield SM, Teare J, O'Doherty MJ. Ulcerative colitis disease in HIV-positive patients with CD4 counts less than 50 cells $/ \mathrm{mL}$ (12). Azathioprine and 6-mercaptopurine are effective in active UC $(13,14)$ but may cause lymphopenia and pancreatitis, adverse effects shared with antiretroviral agents. Cyclosporine is effective in acute severe UC unresponsive to corticosteroid therapy (15) but has significant toxicity and increases the risk for opportunistic infection. Colectomy does not carry an increased risk for infection, although the risk for pouchitis is unknown.

\section{CONCLUSIONS}

The presence of active UC in an HIV-infected individual with a subnormal CD4 cell count is a complex problem because the most potent medical therapies for UC increase the risk of developing infection, and HIV is associated with intestinal infections that can exacerbate UC symptoms, truly a 'pas de deux'. It also raises interesting questions about IBD pathogenesis and challenges the clinician to manage an active inflammatory process in an immunocompromised patient.

developing after amoebic dysentery in a haemophiliac patient with AIDS. Gut 1992;33:408-10.

8. May GR, Gill MJ, Church DL, Sutherland LR. Gastrointestinal symptoms in ambulatory HIV-infected patients. Dig Dis Sci 1993;38:1388-94.

9. René E, Marche C, Chevalier T, et al. Cytomegalovirus colitis in patients with acquired immunodeficiency syndrome. Dig Dis Sci 1988;33:741-50.

10. Wajsman R, Cappell MS, Biempica L, Cho KC. Terminal ileitis associated with cytomegalovirus and the acquired immune deficiency syndrome. Am J Gastroenterol 1989;84:790-3.

11. Bernstein BB, Gelb A, Tabanda-Lichauco R. Crohn's ileitis in a patient with longstanding HIV infection. Am J Gastroenterol 1994;89:937-9.

12. Nelson MR, Erskine D, Hawkins DA, Gazzard BG. Treatment with corticosteroids - a risk factor for the development of clinical cytomegalovirus disease in AIDS. AIDS 1993;7:375-8.

13. Kirk AP, Lennard-Jones JE. Controlled trial of azathioprine in chronic ulcerative colitis. BMJ 1994;284:1291-2.

14. Adler DJ, Korelitz BI. The therapeutic efficacy of 6-mercaptopurine in refractory ulcerative colitis. Am J Gastroenterol 1994;85:717-22.

15. Lichtiger S, Present DH, Kornbluth A, Hanauer S. Cyclosporine in severe ulcerative colitis refractory to steroid therapy. N Engl J Med 1994;330:1841-5. 


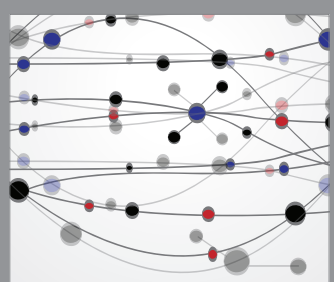

The Scientific World Journal
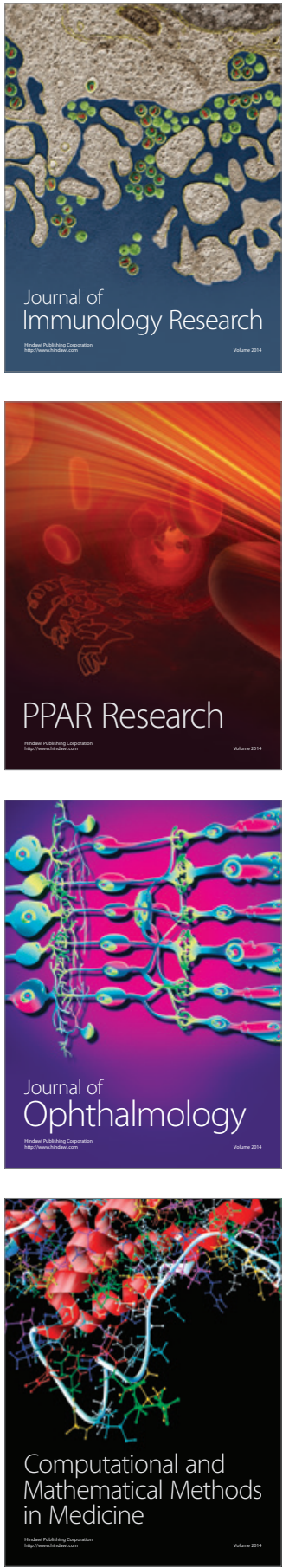

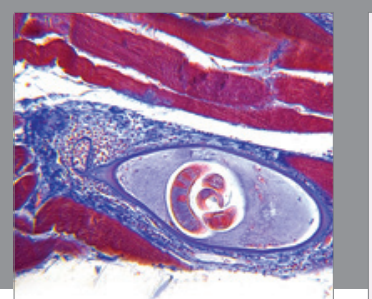

Gastroenterology Research and Practice

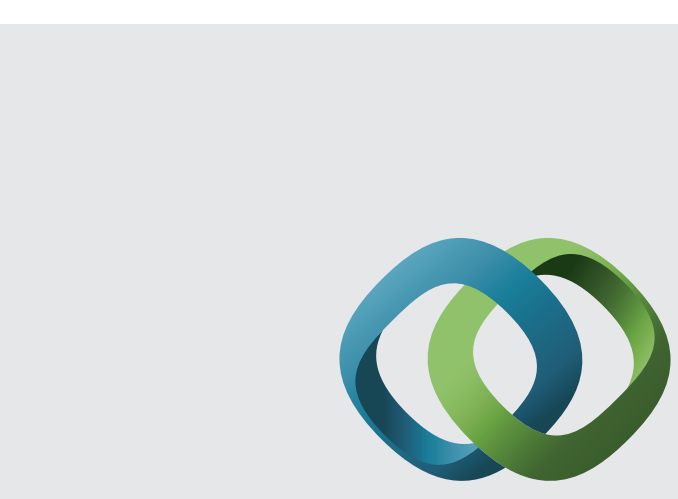

\section{Hindawi}

Submit your manuscripts at

http://www.hindawi.com
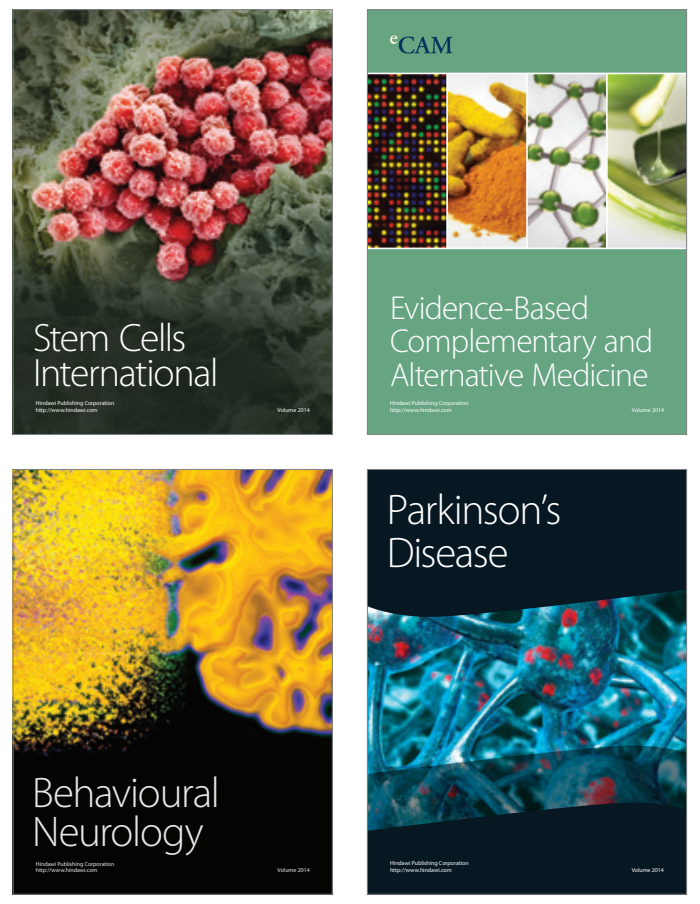
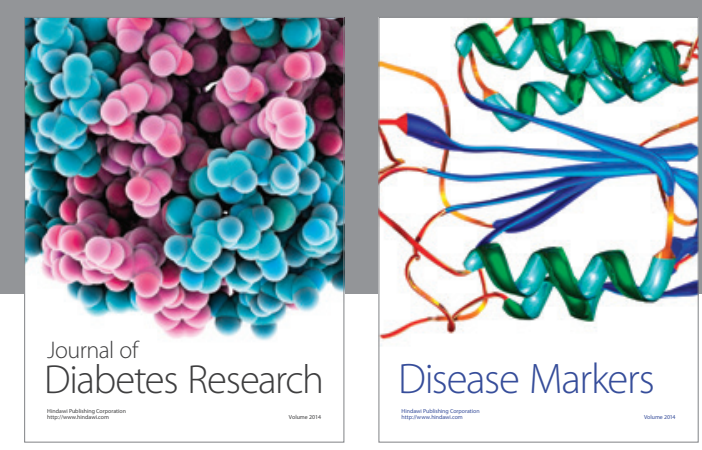

Disease Markers
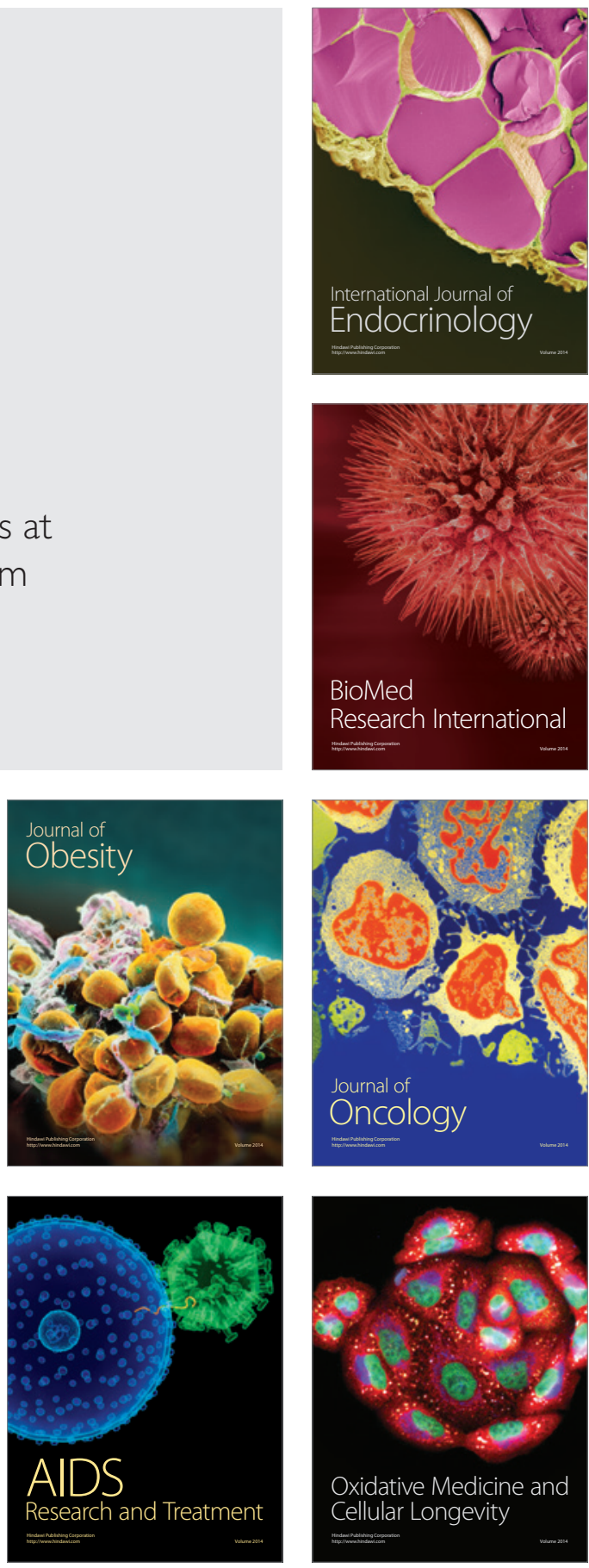